\title{
Management of Admission of New Learners Zoning System to Equalize the Quality of Educational Services to Learners
}

Eva Nurhasanah, Didin Wahidin, Teti Ratnawulan, Hanafiah

Mahasiswa Pascasarjana Universitas Islam Nusantara, Bandung, Indonesia

Universitas Islam Nusantara, Bandung, Indonesia

Email: evahasanah1112@gmail.com, didinwahidin@uninus.ac.id, tetiratnawulan@uninus.ac.id, hanafiah@uninus.ac.id

\section{ARTICLE INFO ABSTRACT}

Received

10 September 2021

Revision

11 September 2021

Approved

19 September 2021

Keywords:

Management;

PPDB;

Zoning;

Equity;

Quality
The gap in the quantity and quality of education between regions, discrimination, and injustice in access and education services is exacerbated by the dichotomy of only and non-superior schools widening the gap in the quality of education in Indonesia. To increase the distribution of quality and equitable quality education services to students, a zoning system PPDB management is needed. On that basis, this study aims to describe the PPDB management of the zoning system to equalize the quality of education services for students at the Tasikmalaya Regency State Senior High School, which includes planning, organizing, preparing personnel, implementing, coordinating, reporting, and budgeting. This research uses a qualitative approach with the type of case study. The research location is SMA Negeri 1 Ciawi, SMA Negeri 1 Karangnunggal and SMA Negeri 1 Cikalong, Tasikmalaya Regency. This study resulted in that: 1) Planning for the zoning system PPDB includes setting goals, formulating current conditions, identifying facilities and obstacles, and developing a series of activities. 2) Organizing the zoning system PPDB includes preparing the organizational structure, dividing workloads, and determining the lines of coordination and authority. 3) Preparation of PPDB personnel for the zoning system includes needs analysis, recruitment of committees according to the main tasks and functions, and training of organizing committees to work according to their duties and functions. 4) Implementation includes PPDB registration, data verification, and selection of prospective students, meeting to determine PPDB selection results, the announcement of PPDB results, and reregistration. 5) Coordination includes coordination with internal schools and coordination with external schools. 6) Reporting includes reports on recapitulation of re-registration received and re-registration, class division, submission of student files to $\mathrm{BP} / \mathrm{BK}$ and student affairs, evaluation, and preparation of reports. 7) Budgeting includes budget planning and realization of budget use. 8) Obstacles can be seen from technical and non-technical constraints. 9) Solutions and improvement efforts can be seen from technical solutions and non-technical solutions.

\section{INTRODUCTION}

The government has an obligation to carry out the education process for the whole community well, which is based on an awareness of the importance of education for life (Khadowmi, 2019), one of the efforts made by the government is the improvement

Published By: $\quad$ Ridwan Institut 
of the New Student Admissions system (PPDB) which has a lot of reaping problems starting from various mistakes (Karmila, Syakira, \& Mahir, 2020), goals that are carried out in a planned, regular, directed, and sustainable manner. This has been regulated in Law Number 20 of 2003 concerning the "National Education System" in the section considering point (c), "The National Education System must be able to guarantee, equal distribution of educational opportunities, quality improvement, as well as the relevance and efficiency of education management to face challenges. demands for changes in local, national, and global life, so it is necessary to carry out educational reforms in a planned, directed, and sustainable manner." Because schools usually maintain the "status quo", as a result, the quality of education services is uneven and fair to serve children in every remote area of the country (dan Kebudayaan, 2018).

Then in article 11 of Law no. 20 of 2003 also mandates that "The Government and Regional Governments are obliged to provide services and facilities, as well as ensure the implementation of quality education for every citizen without discrimination." The article explains that every citizen must have the opportunity to receive an education. The government is fully responsible for fulfilling the rights of its citizens by organizing an education system in an objective, accountable, transparent, and non-discriminatory manner to encourage the equal distribution of the quality of education services.

The quality reference used for achieving or fulfilling the quality of education in academic units is the National Education Standards (SNP). According to (Putra \& Widnyani, 2020), "The National Education Standard (SNP) is the minimum criterion regarding the education system in all jurisdictions of the Unitary State of the Republic of Indonesia."

Furthermore, according to Permandisbud Number 28 of 2016 article 7, there are eight SNPs, namely:

a. Assessment results

b. Education Content

c. Educational Process

d. Educational Assessment

e. Teachers and Education Personnel

f. Educational Facilities and Infrastructure g. Education Financing

h. Education Management

The eight SNPs above are related to each other and must be fulfilled by the education unit to fulfill quality education services for students. However, the current quality of educational services seems practical to give a different treatment where certain schools are called only schools or favorite schools. Favorite schools are considered capable of providing the best service. As a result, particular residents and community groups cannot get quality educational services due to geographical factors, transportation constraints, accommodation, and others due to the existence of superior or favorite schools generally located in big cities.

In addition, with coaching orientation and special treatment for schools only or favorites, all resources are given to these schools. Meanwhile, regular schools receive less attention so that schools do not develop, while special schools become the center of attention and continue to be given excessive assistance and support.

Therefore, policies in education must be established, in order to provide a strong basis for a student who wants to carry out a profession (Asri, Visayanti, \& Arnilawati, 2020).

Various efforts are being made by the government to encourage equity in education at this time, one of which is by improving the New Student Admission (PPDB) system by implementing the zoning system policy in the 2018 PPDB.

The education zone begins with the issuance of Regulation of the Minister of Education and Culture Number 17 of 2017 concerning Admission of New Students to Kindergarten, Elementary Schools, Junior High Schools, Senior High Schools, Vocational High Schools, or other equivalent forms to become the basis for developing the system. zoning on other educational issues. However, what is often found in the field is a zoning system that collects children with conditions that are not much different to become a separate complaint for teachers in order to deal with student behavior that increases "sloppy" or undisciplined, this needs to be addressed immediately because it is related to student achievement. (Nurlailiyah, 2019), Because the human resources expected from schools are quality graduates (Saril, 2019) 
In 2018, the PPDB Zoning regulation was updated to become the Minister of Education and Culture Regulation Number 14 of 2018, which was issued on May 7, 2018, concerning the Admission of New Students (PPDB) in Kindergarten, Elementary School, Middle School, High School, Vocational High School, or other equivalent forms. The Minister of Education and Culture contains many provisions regarding the procedure for accepting new students. Still, a critical point of this regulation is the change in the reference made to determine whether or not a prospective student is taken to the relevant state school.

Permendikbud No. 14 of 2018 Article 16 paragraph 1 explains that "Schools organized by local governments are required to accept prospective students who are domiciled in the radius of the closest zone to the school at least $90 \%$ (Ninety percent) of the total number of students accepted". The zoning system policy is the main criterion in the PPDB system that looks at the distance between the prospective student's residence and the education unit.

In December 2018, the government made new rules related to PPDB for the 20192020 Academic Year, namely Permen-disbud No. 51 of 2018, which was later renewed with Permendikbud 20 of 2019. In Permen-disbud No. 20 of 2019 Article 16 paragraph 2, "The zoning route as referred to in paragraph (1) letter $a$ is at least $80 \%$ (eighty percent) of the school's capacity".

Then in the 2020-2021 Academic Year, the government makes new rules regarding PPDB policies, namely Permen-disbud Number 44 of 2019, wherein Article 11 paragraph 2 it is stated that "The zoning lane as referred to in paragraph (1) letter $a$ is at least $50 \%$ (fifty percent) percent) of the school's capacity".

According to (Rachmadhany, Matin, \& Sugiarto, 2020), "There are three things that the government wants to achieve in providing complete services in the field of education to the community. All three relate to availability, affordability, and quality. That's why the various policies issued are always based on these three things-no exception to the zoning policy in the Registration of New Students. The zoning policy has a clear goal so that the quality of schools can be evenly distributed.
The zoning system is rated very well; zoning policy regulations continue to be updated to improve PPDB, but still invite various public reactions; Pros and cons also occur in various circles of society because its implementation has led to several new development problems.(Kemdikbud, 2018)

The government's strategy to accelerate the distribution of quality education in Indonesia through the PPDB zoning system is still inadequate. According to data from the Central Statistics Agency (https://bps.go.id.) in 2019, the APK (Garden Participation Rate) of West Java Province Senior High Schools was $77.82 \%$, which means that there are about $22 \%$ of West Java's population aged 16-18. years who have not had access to education at the high school level. Meanwhile, West Java's APS (School Participation Rate) at the age of 1618 years is $67.29 \%$ and is the second-lowest APS among other provinces located on the island of Java.

In connection with the PPDB problem with the zoning system, the author conducted preliminary research on several schools in Tasikmalaya Regency.

Based on the results of preliminary research regarding the PPDB of the zoning system in Tasikmalaya Regency, it turns out that the PPDB of the zoning system is still reaping problems, including:

1. The government's lack of preparation, especially zoning and registration procedures, makes the public confused because there has been no prior socialization and information.

2. The obligation to accept a minimum of $50 \%$ of prospective students who live in locations near the school makes schools far from the concentration of residential residents with low interest or lack of registrants. On the contrary, schools located in congested zones (urban centers and schools) in favorite value) there is still an excess of registrants/over quota;

3. A child's good academic grades become "not counted" as crucial because the main thing is the location and position of their residence so that many children who excel outside the zone are not accepted;

4. They are relating to a sudden change of residence. There are still several cases of children entrusted with their names on the Family Cards of their relatives in the 
zoning radius of the school they are interested in.

5. With the decline in student achievement due to zoning, learning achievement is not the primary requirement in registering schools.

6. Error in determining the coordinates through GPS, so that some students whose distance is close are not accepted because the coordinates are outside the zoning point;

7. The decline in school grades is because anyone in the school zone can be accepted with good quality without competing for grades.

8. Infrastructure facilities have not met the standard equally to every school;

9. The $20 \%$ quota for the SKTM Path (students who come from underprivileged families) causes many people to make fake SKTMs, and prospective students who excel are eliminated with the $20 \%$ quota, and there are many other problems.

Preliminary research at several public high schools in Tasikmalaya Regency shows that the PPDB zoning system has not been managed optimally. It hurts the equitable distribution of education service quality. These problems need further research to find valid data and, at the same time, determine alternative solutions. For this reason, the author is interested in conducting further research on 3 (three) public high schools in Tasikmalaya Regency, namely SMA Negeri 1 Ciawi Tasikmalaya, SMA Negeri 1 Karangnunggal, and SMA Negeri 1 Cikalong, because these three schools have unique problem characteristics related to PPDB problems with the Zoning system.

In connection with this, the researchers determined the title of the study about Management of New Student Admissions Zoning System to Equalize the Quality of Education Services for Students at SMA Negeri Tasikmalaya Regency (Case Study at SMA Negeri 1 Ciawi, SMA Negeri 1 Karangnunggal and SMA Negeri 1 Cikalong Regency Tasikmalaya).

\section{METHODE}

This research uses a qualitative approach with the type of case studytechnical data collection through in-depth interviews, observation, and documentation. The data collection step is through the orientation, exploration, and member check stages. The data analysis steps are through the stages of data collection, data reduction, data presentation, concluding, and verification. The data validity technique is carried out through reliability, dependability, transferability, and confirmability.

\section{RESULTS AND DISCUSSION}

A. Planning PPDB Zoning System

Based on the research findings, it was obtained data that the three schools had implemented reasonable, measurable, and comprehensive planning, which included four stages, namely setting goals, formulating the current situation, identifying all facilities and obstacles, and developing a series of activities. This is in Handoko's opinion (Handoko, 2009) revealed that planning provides several details regarding planning activities, which go through four stages, namely:

1. Setting a goal or set of goals

2. Formulate the current state

3. Identify all facilities and obstacles

4. Develop a plan or series of activities for the achievement of goals.

The zoning system prioritizes distance in accepting new students so that students tend to have different backgrounds. The zoning system allows anyone to enroll in a school close to where they live. This is by the opinion of (Jaryono, Naufalin, Krisnaresanti, \& Dinanti, 2020): The zoning system is expected to realize quality education through equal distribution of education and improvement of the education system. The zoning system prioritizes distance in accepting new students. Thus students tend to have different backgrounds. The zoning system allows anyone to register at a school close to where they live.

\section{B. Organizing PPDB Zoning System}

Based on the research results, information was obtained that the organization of the three schools was quite good. In principle, the three schools have made organizational stages by the 
PPDB technical guidelines by upholding the PPDB principles.

Organizing in the implementation of PPDB is a committee organization where the performance of PPDB is formed by a committee at the provincial level as the coordinator and the education unit level as the implementer.

Based on the PPDB technical instructions, the three schools have set up a committee by the technical education that has been set. Some schools make adjustments but do not violate the rules.

\section{Determination of Zoning System PPDB Personnel}

Based on the research results, it is known that in determining the personnel of the committees, the three schools have started with a needs analysis based on the type of work, the nature of the work, and the estimated workload. Then recruit committees from internal schools by direct appointment and acclamation selected from people who are considered to know about handling the activities held. Explained that the determination of committee personnel was carried out by taking into account:

1. The committee's composition is prioritized using an internal recruitment pattern adjusted to the hierarchical structure and division in the organizational structure, except when the activities concerned require personnel with particular criteria.

2. The pattern of committee recruitment is carried out based on the following considerations:

3. personnel capabilities related to the scope of activities;

4. personal existence, which involves credibility, performance, insight, integrity, honesty, and sincerity in carrying out tasks;

5. the ability of personnel to utilize facilities and infrastructure in an effective, efficient, and transparent manner.

\section{PPDB Zoning System Briefing}

Based on the results of the research, it is known that the PPDB stages of the zoning system are by the regulation of the Minister of Education and Culture No. 44 of 2019 and the West Java PPDB technical guidelines for 2020/2021, where the implementation of the zoning system PPDB goes through the following PPDB stages:

1. Announcement of registration;

2. Registration Preparation;

3. Registration;

4. Data verification of Prospective Students;

5. Implementation of selection;

6. Meetings (online/online) to determine PPDB (teachers and school principals);

7. Coordination (online/online) of education units with the Education Office;

8. Announcement of PPDB results;

9. Re-registration.

\section{E. Coordination of PPDB Zoning System}

Based on the study results, it can be seen that the three schools have implemented internal coordination at every stage of management, from implementation to reporting. Coordination is an activity related to efforts to unite and direct the activities of all elements of the organization so that every movement and step is aimed at the goal. This is by (Malayu 2003) that "Coordination is the activity of directing, integrating, and coordinating elements of management and the work of subordinates in achieving organizational goals."

\section{F. PPDB Zoning System Report}

Based on the study results, it can be seen that the three schools reported PPDB results to the West Java Provincial Office through the Regional XII Office Branch Office. The reporting sequence consists of recapitulating student data received and re-registered, class division, submitting 
student files to BK and student affairs, evaluating and preparing activity reports.

In West Java Governor Regulation Number 31 of 2020 article 34 paragraph (1), it is explained that "the Education Unit implementing the PPDB reports the implementation of the PPDB to the Head of Service." Then in the PPDB technical instructions, West Java explains that "Education units are required to report the implementation of PPDB and the transfer of students between educational units every academic year to the Regional Government by their authority (Tsai, n.d.)."

PPDB reporting on the zoning system is not carried out separately but is integrated with the PPDB report as a whole. From the study results, it can be seen that the three schools reported a recapitulation of the data re-registration of students who were accepted and those who re-registered where it was known that all students who were born reregistered.

\section{G. PPDB Zoning System Budgeting}

Based on the study results, it can be seen that in the budgeting of the three schools, the source of the budget is from the School Operational Assistance fund. This is by the opinion of Nurjainingsih, who explained that "PPDB financing according to Permendikbud number 51 of 2018 is entirely derived from BOS funds. So that registrant are not charged anything.

Budgeting is a critical stage in an organization and educational institutions such as schools. According to (Fattah, 2004) "budgeting is an activity or process of preparing a budget (budget)."

The results showed that budget planning at the three schools still prioritized budget allocations for consumption and transportation by the committee. And the absorption capacity of the budget for consumption and transportation of the committee turned out to be more than $50 \%$. The budgeting objectives must be focused on improving student learning and prioritizing spending for school development.

\section{H. Constraints faced in PPDB Zoning System}

In its implementation, PPDB 2020 from the three schools studied faced several obstacles. These various obstacles can be grouped into two things, firstly technical constraints, secondly related to non-technical controls.

The technical obstacles to implementing PPDB 2020 in the field are mostly server problems and heavy internet traffic. Then the internet network is not evenly distributed in the zoning area.

Second, there are many invalid coordinates due to the unreadable coordinates of the application, the registrant's inaccuracy before recording the coordinates, and the registrant's incomprehension in determining the coordinates themselves.

Third, not all schools of origin and parents of prospective new students have adequate IT equipment, so the PPDB committee of the original school came to the destination school to register online with the assistance of the school operator. Fourth, many registrants who enter the requirements in PPDB online have a disability. Many of these problems arise from a lack of understanding of the procedures and techniques for implementing the zoning system.

Meanwhile, the non-technical problems experienced by the three schools include the unequal distribution of teaching staff and education staff and educational infrastructure. Is this course not by the objectives of PPDB wherein point 4 of the Ministry of Education and Culture (2018:4) "Ensuring the fulfillment of competent educators and educational staff supported by adequate infrastructure and facilities that can be provided and 
used together by each educational unit that is is in the designated area/zone?"

Then the paradigm of the favorite school is still attached to the community. The same problem was also expressed by (Tsai n.d.) "the dichotomy perception of favorite schools remains to affect parents and students in terms of choosing the school." The dichotomy of perceptions of favorite schools still influences parents and students in choosing schools. Of course, the reality on the ground is in stark contrast to the aim of implementing the PPDB zoning system itself, which is to abolish the label of favorite or excellent school in the community".

Furthermore, the zoning system with distance priority causes students' learning motivation to decrease because grades or achievements are considered unimportant. PPDB zoning system is deemed to reduce interest in learning and limit their right to attend the desired school so that they assume that no matter how high their grades are, they cannot choose a school. Motivation within the individual is a force that can encourage individuals to realize a behavior to achieve the goals to be completed (Handoko, 2016).

The PPDB policy of the zoning system should encourage the creativity of educators in heterogeneous classes. Sutikno M.S explains that "the success or failure of achieving educational goals depends greatly on how the teaching and learning process is designed and carried out professionally." Therefore, the role of heterogeneous classroom management for teachers is needed so that learning becomes effective, conducive, efficient, and fun (Fathurohman dan Sutikno, 2011).

\section{Solutions and Improvement Efforts in PPDB Zoning System}

Based on the study results, it can be seen that the three schools describe solutions to problems both technically and non-technically caused. In essence, these solutions or improvement efforts cannot be resolved only by internal schools' government intervention as policyholders and guides play an essential role.

New Student Admission (PPDB) with a zoning system is one of the four main programs of the "Learning Independence" education policy. It is hoped that the implementation of PPDB will be more flexible to accommodate inequality in access and quality of education in various regions (Richardo, 2016).

Solutions that can be done include the government immediately providing adequate infrastructure or facilities. By the Law of the Republic of Indonesia No. 20 of 2003 Article 45 Paragraph (1) "Every formal and non-formal education unit provides facilities and infrastructure that meet educational needs by the growth and development of the physical, intellectual, social, emotional, and psychological potential of students"

This article relates to the procurement and utilization of educational resources that the government, the community must carry out and the families of students who are partners in organizing education. All three should be jointly responsible within the limits of their respective abilities or professionally in the planning field. Procurement, implementation, and supervision, so that education at any level is not only left to schools to handle.

This is in line with the research of Dewi and Septiana "The effectiveness of a system's facilities and infrastructure occurs if all work together and provide mutual support. Like what happened to PPDB in suburban schools in the Tulungagung Regency area, all education components work together to maximize PPDB facilities and infrastructure. As a result, PPDB activities in each school experienced things that were more effective than before" (Dewi \& Septiana, 2018). 
Then the three schools revealed that the distribution and quality of teachers. Zoning regulates the quality of schools and students and focuses on the role and composition of teachers in an area. According to the three schools, these policies must be harmonized with the distribution and quality of teachers in all regions. This is in line with the opinion of Ferdiansyah "In terms of quantity, the ratio of teachers and students is on average 1 to 16 at each level of education" (Suryahadikusumah, Kurniasari, Ferdiansyah, Purnamasari, \& Surtiyoni, 2019).

The socialization process also plays an essential role before issuing a policy, the central, regional, and educational units need to carry out massive socialization. The implementation of PPDB, which has a vast scope, requires a particular socialization strategy. In this case, a bureaucracy that can communicate with those who make policies and implement policies is necessary. The socialization mechanism must be carried out in a planned, integrated, and continuous manner to ensure the growth of the common perception and motivation in supporting the zoning policy. The government needs to use various networks more intensively to facilitate the socialization process. With the massive socialization, it is hoped that the understanding of the community and local government regarding zoning will be by the policy's objectives. Is this important to reduce deviations in the implementation of the policy.

Furthermore, in determining zones, local governments are expected to pay more attention to several factors such as data collection on population, school distance, and school access from several areas. The number of prospective students who will enter SD, SMP, and SMA needs to be recorded and harmonized with the capacity of public schools in each zone.
Furthermore, the division of zoning also needs to pay attention to prospective students located on the zoning border to be accommodated in public schools. Meanwhile, to overcome the gap in the capacity of public schools with the number of applicants, currently, several regions are trying to add New Classrooms (RKB) or New School Units (USB).

Parents must change their perspective on excellent schools to eliminate the dichotomy of excellent and non-excellent schools. The mindset of parents needs to be directed at the concept of schools only facilitating students. Achievement is not measured from school origin but from each individual. Related to this, the government needs to educate parents of students about the long-term goal of the zoning system, namely equal distribution of quality education, so that parents and prospective students have the awareness that all schools are essentially good.

\section{CONCLUSION}

1) The PPDB planning for the zoning system at SMA Negeri has been carried out properly, measurably, and comprehensively which includes four stages, namely setting goals, formulating the current situation, identifying all facilities and obstacles, and developing a series of activities.2) Organizing the PPDB zoning system to equalize the quality of education services for students has been carried out by the PPDB technical guidelines starting from the preparation of the organizational structure and division of tasks and the determination of authority and responsibility for the leadership all personnel involved in the organization.3) The preparation of PPDB personnel for the zoning system to equalize the quality of education services to students is simpler in stages because PPDB is an incidental committee formed and dissolved after the activity is completed. Schools recruit or form committees based on deliberation and 
consensus appointed by the deputy headmaster, educators, and education staff who are considered competent and have high integrity and are endeavored to take turns every year. 4) The direction of the PPDB zoning system to equalize the quality of education services to students is carried out by the regulations of the Minister of Education and Culture No. 44 of 2019, through the stages of PPDB registration, data verification and selection of prospective students, meeting to determine PPDB selection results, the announcement of PPDB results and re-registration. Based on the final results of the calculation of new student admissions, it was found that there were schools that met the quota target, and there were also schools that had not reached the quota target, especially in small schools.5) Coordination of PPDB zoning system to equalize the quality of education services to students in the schools studied. There are similarities where coordination is carried out both in the internal and external scope of the school.6) PPDB reporting on the zoning system to equalize the quality of education services for students is reported to the West Java Provincial Office through the Regional XII Office Branch Office. As for the preparation of the report, there is no uniformity of writing systematics due to the absence of standardization, so that it impacts evaluating the achievement of objectives.7) The PPDB budgeting for the zoning system to equalize the quality of education services for students comes from BOS funds and does not charge any new prospective students. The absence of standardization of budget posts and the maximum use of the budget that can be used from BOS funds makes each school have different standards.8) Constraints of the PPDB zoning system to equalize the quality of education services for students are divided into technical limitations, especially the availability of internet networks that are not evenly distributed in each zoning area; there is a lack of public understanding in PPDB technicality as a result of socialization that has not been massive, errors in determining coordinate points, as well as fraud in fulfilling PPDB requirements. Then non-technical constraints, especially geographical constraints, unequal distribution of school infrastructure, and a shortage of educators and education personnel.9) The PPDB solution for the zoning system to equalize the quality of education services to students in terms of technical and non-technical solutions requires cooperation and responsibility from all parties, including schools, government, stakeholders, and the community. The solutions that can be done to overcome technical obstacles include the government immediately equipping IT infrastructure facilities in each education unit equally; decisive action against fraud; and carry out mapping so that children living in areas with minimal public schools can still be facilitated, for example with a contiguous zone policy. As for technical solutions with the recruitment of PNS teachers, teacher zoning or periodic teacher transfers, more intensive and massive socialization, teacher training, equal distribution of National Education Standards (SNP) through the BERMUTU program, and evaluation of PPDB policies in 2018 to better adapt field conditions in various regions so that next year there will be improvements in the PPDB system;

\section{REFERENCES}

Asri, Asri Yani, Visayanti, Visayanti, \& Arnilawati, Rina Arnilawati. (2020). Analisis Kebijakan Pendidikan Terkait Peningkatan Kinerja Guru. Jurnal Mappesona, 2(1).Google Scholar

Dan Kebudayaan, Kementerian Pendidikan. (2018). Sistem Zonasi Strategi Pemerataan Pendidikan Yang Bermutu Dan Berkeadilan. Jakarta: Pusat Data Dan Statistik Pendidikan Dan Kebudayaan. Google Scholar

Dewi, Kiki Engga, \& Septiana, Ririn. (2018). Evaluation Of Zoning Student Recruitment System In Year 2018. 
Proceeding International Seminar On Education. Google Scholar

Fattah, H. Nanang. (2004). Konsep Manajemen Berbasis Sekolah (Mbs) Dan Dewan Sekolah. Pustaka Bani Quraisi. Google Scholar

Handoko, T. Hani. (2009). Manajemen, Cet. Ke-2. Yogyakarta: Bpfe-Yogyakarta. Google Scholar

Handoko, T. Hani. (2016). Manajemen Personalia Dan Sumberdaya Manusia. Bpfe. Google Scholar

Jaryono, Tohir, Naufalin, L., Krisnaresanti, Aldila, \& Dinanti, Aldila. (2020). Analysis Of Zonation System Implementation On The Behavior Of High School Students In Banyumas District. International Journal Of Economics, Business And Management Research, 4(12), 252-257. Google Scholar

Karmila, Mila, Syakira, Niswatu, \& Mahir, Mahir. (2020). Analisis Kebijakan Pendidikan Sistem Zonasi Dalam Penerimaan Peserta Didik Baru. Jurnal Mappesona, 2(1). Google Scholar

Kemdikbud, Pengelola Web. (2018). Kemendikbud: Sistem Zonasi Mempercepat Pemerataan Di Sektor Pendidikan. Kemdikbud. Https://Www. Kemdikbud. Go. Id/Main/Blog/2016/05/Rumahkunci .... Google Scholar

Khadowmi, Eka Reza. (2019). Implementasi Kebijakan Sistem Zonasi Terhadap Proses Penerimaan Peserta Didik Baru Kabupaten Lampung Tengah. Google Scholar

Malayu, S. P. Hasibuan. (2003). Manajemen Sumber Daya Manusia, Edisi Revisi Bumi Aksara. Jakarta: Grasindo. Google Scholar

Nurlailiyah, Aris. (2019). Analisis Kebijakan Sistem Zonasi Terhadap Perilaku Siswa Smp Di Yogyakarta. Realita: Jurnal Penelitian Dan Kebudayaan Islam,
171). Google Scholar

Putra, I. Rai Wahyudi, \& Widnyani, Ida Ayu Putu Sri. (2020). Implementasi Peraturan Menteri Pendidikan Dan Kebudayaan Nomor 28 Tahun 2016 Tentang Sistem Penjaminan Mutu Pendidikan Dasar Dan Menengah Di Smp Negeri 3 Mengwi. Locus, 12(1). Google Scholar

Rachmadhany, Fitri, Matin, Matin, \& Sugiarto, Sugiarto. (2020). Evaluation Of Policy Implementation Admission New Students By Zonation System In Senior High School Bekasi District. Edutec: Journal Of Education And Technology, 4(2), 130-146. Google Scholar

Richardo, Rino. (2016). Program Guru Pembelajar: Upaya Peningkatan Profesionalisme Guru Di Abad 21. Prosiding Seminar Nasional Matematika Dan Pendidikan Matematika. Google Scholar

Saril, Saril. (2019). Total Quality Management (Tqm) Sebagai Wujud Peningkatan Mutu Pendidikan. Adaara: Jurnal Manajemen Pendidikan Islam, 9(2), 963-972. Google Scholar

Suryahadikusumah, Ahmad Rofi, Kurniasari, Kurniasari, Ferdiansyah, Muhammad, Purnamasari, Syska, \& Surtiyoni, Endang. (2019). Mempersiapkan Karir Siswa Di Era Digital Melalui Pemahaman Tipologi Kepribadian Dan Dunia Kerja. Widya Laksana, 8(2), 119-124. Google Scholar

Tsai, Hsiu Mei. (N.D.). A Study Of Student Admission By School Zoning System In Indonesia: Problem Or Solution? National Chung Cheng University Taiwan 2020. Google Scholar 


\section{Copyright holder :}

Eva Nurhasanah, Didin Wahidin, Teti Ratnawulan, Hanafiah (2021)

First publication right :

Journal of Social Science

This article is licensed under:

(c) (i) (2) 